\title{
PERAN BUDAYA ORGANISASI TERHADAP PENGAMBILAN KEPUTUSAN
}

\author{
Pandu hidayat, Muh.Alhadid \\ Panpandupan13@gmail.com \\ Alhadid03@yahoo.com
}

\section{Fakultas Ekonomi dan Bisnis Universitas Narotama}

\begin{abstract}
ABSTRAK
Tujuan dari studi ini adalah untuk mengetahui secara jelas apakah pengertian budaya organisasi secara jelas dimulai dari pengertian peranan dan syarat yang efektif yang diperlukan bagi seorang pemimpin untuk mengambil keputusan untuk kelanjutaan organisasi baik di perusahaan maupun di lingkungan masyarakat. Penelitian ini menggunakan kombinasi pendekatan kuantitatif. Penelitian ini menggunakan total sampling seluruh karyawan Rumah Kopi dan Galeri Seni Kopiganes yaitu sebesar 10 orang dengan informan manajer Rumah Kopi dan Galeri Seni Kopiganes. Hasil dari penelitian ini yaitu budaya organisasi sangat berpengaruh signifikan terhadap pengambilan keputusan manajer Kopiganes.

Kata Kunci : Budaya organisasi, pengambilan keputusan, kedai rumah kopi
\end{abstract}




\section{PENDAHULUAN}

\section{Latar belakang}

Kurangnya pemahaman budaya organisasi pada leader suatu perusahaan akhirakhir ini menimbulkan adanya kesalahan dalam pengambilan keputusan. Kesalahan presepsi dan ketidak tahuan seorang leader terhadap budaya organisasi ini menimbulkan turunnya semangat berorganisasi pada bawahannya. Sehingga sangatlah penting mengetahui budaya organisasi dalam pengambilan keputusan.

Budaya organisasi dibentuk oleh sejarah panjang, sejak didirikan, mengalami transisi, hingga menjadi organisasi stabil dan berkembang pesat. Nilai-nilai dasar dianggap sesuatu yang sangat prinsip karena menyangkut keyakinan, asumsi-asumsi dasar yang telah mereka hayati selama bergelut di organisasi. Pada akhirnya melahirkan jejak-jejak dalam bentuk prestasi, produk, dan layanan berkualitas. Singkatnya, budaya organisasi menyangkut seluruh sendi kehidupan organisasi, bersifat abstrak juga nampak dalam perilaku fisik. Menurut (Ida Ayu Brahmasari \& Agus Suprayetno, 2008) pemimpin harus membentuk iklim organisasi melalui budaya organisasi sehingga para karyawan merasa terpacu untuk bekerja lebih keras agar kinerja yang dicapai juga tinggi.

Pada pengambilan keputusan berarti memilih yang terbaik dari deretan alternatif yang tersedia. Fungsi adanya budaya organisasi adalah sebagai pedoman dan arah setiap alternative di analisis dengan cara menggunakan budaya organisasi yang dianut masing masing organisasi yang dikemukakan oleh (Hamka, 2017). Oleh karena itu penulis tertarik melakukan penelitian karena banyaknya budaya yang ada di Indonesia sedikit mempengaruhi budaya organisasi dan prespektif di dalam organisasi. 


\section{Rumusan Masalah}

1. Apa pengertian budaya organisasi?

2. Apakah peranan budaya organisasi berpengaruh pada pengambilan keputusan berorganisasi?

\section{Tujuan Penelitian}

Tujuan penulisan makalah ini yaitu Untuk mengetahui secara jelas apakah pengertian budaya organisasi secara jelas dimulai dari pengertian peranan dan syarat yang efektif yang diperlukan bagi seorang pemimpin untuk mengambil keputusan untuk kelanjutaan organisasi baik di perusahaan maupun di lingkungan masyarakat.

Dengan mengetahui hal itu penulis berharap pemimpin bisa mengerti pentingnya memahami budaya organisasi dari organisasi itu sendiri, untuk pengambilan keputusan yang tepat supaya organisasi dapat menjadi lebih baik. Dan melatih mahasiswa agar lebih memahami tentang pokok bahasan khususnya budaya organisasi. 


\section{TINJAUAN PUSTAKA}

\section{Penelitian Terdahulu}

Menurut (Tarbiyah, 2017) pada penilitiannya ialah budaya organisasi ibarat sebuah bangunan yang terdiri dari beberapa lapis, seperti nilai-nilai (Values) di level atas, asumsi dasar (Basic Assumptions) pada level tengah. Dan artefak (Artefacts) pada level bawah. Lapisan-lapisan dalam budaya organisasi merupakan satu kesatuan utuh tak terpisahkan. Dalam kontruksi demikianlah yang menggambarkan secara keseluruhan sebuah organisasi. Salah satu aspek yang dipengaruhi oleh budaya organisasi adalah pengambilan keputusan. Kebijakan strategis yang diturunkan dalam keputusan strategik bukanlah factor yang berdiri sendiri dalam kehidupan organisasi, tetapi mengacu pada budaya yang terbangun pada organisasi tersebut.

Menurut (Nurhidayati, 2015) pada penelitiannya ialah berdasarkan analisis data, maka dapat disampaikan kesimpulan sebagai berikut: 1) Terdapat pengaruh langsung positif budaya organisasi terhadap pengambilan keputusan, 2) Terdapat pengaruh positif konsep diri terhadap pengambilan keputusan, dan 3) Terdapat pengaruh postif budaya organisasi terhadap konsep diri.

Menurut (Pradhanawati, N, \& Si, 2012) pada penelitiannya menyatakan bahwa budaya organisasi berpengaruh positif dan signifikan terhadap kinerja karyawan. Dengan tujuan penelitian untuk mengetahui pengaruh budaya organisasi terhadap kinerja karyawan dengan melalui disipliin kerja. Penelitian ini menggunakan variable bebas Budaya Organisasi (X1) Gaya Kepemimpinan Transformasional (X2), dan variable intervening Disiplin kerja (Y1) serta variable terikat Kinerja. 
Menurut (Ida Ayu Brahmasari \& Agus Suprayetno, 2008)pada penelitiannya ialah dapat disimpulkan bahwa budaya organisasi berpengaruh positif dan signifikan terhadap kepuasan kerja karyawan dengan tujuan penelitian untuk mengetahui pengaruh budaya organisasi terhadap kepuasan kerja karyawan. Penelitian ini menggunakan variable bebas Motivasi kerja (X1) Kepemimpinan (X2) Budaya Organisasi (X3) dan variable intervening Kepuasan Kerja Karyawan (Y1) serta variable terikat Kinerja Karyawan (Y2).

Menurut (Vitell, Nwachukwu, \& Barnes, 1993) menyatakan bahwa model teoritis etika bisnis telah menyadari pentingnya budaya dalam pembuatan keputusan etis, hanya sedikit yang meneliti bagaimana makalah ini memepengaruhi etika pengambilan keputusan. Dengan variabel bebas budaya (X1) dan etika pengambilan keputusan (Y1) penelitian bertujuan untuk mengembangkan proposisi mengenai pengaruh berbagai perbedaan budaya pada pengambilan keputusan dengan menggunakan tipilogi hofstede.

Beberapa penelitian terdahulu juga membuktikan bahwa budaya organisasi yang dibangun melalui gaya kepemimpinan dapat meningkatkan daya saing umkm dan meningkatkan kinerja karyawan umkm(Alimudin, A., \& Sasono, 2015; Alimudin, A., \& Sukoco, 2017; A. Alimudin, 2015; Arasy Alimudin, 2013; Vitell et al., 1993) 


\section{METODE PENELITIAN}

\section{Metode}

Penelitian ini menggunakan kombinasi pendekatan kuantitatif (metode survei) dan pendekatan kualitatif. Metode survei adalah metode yang mengambil contoh data dari satu populasi dan menggunakan kuesioner sebagai alat pengumpulan data yang pokok (Singarimbun dan Effendi, 1989). Dengan memadukan kedua pendekatan tersebut diharapkan upaya pemahaman gaya kepemimpinan dalam pengambilan keputusan, faktor-faktor yang mempengaruhi gaya kepemimpinan dan pengaruhnya terhadap kinerja karyawan terhadap perusahaan dapat dilakukan secara lebih komprehensif.

\section{Lokasi dan waktu penelitian}

Penelitian ini dilaksanakan di Rumah Kopi dan Galeri Seni Kopiganes J1. Keputih Tegal Timur 2 no 116 Surabaya. Pemilihan lokasi penelitian dilakukan secara sengaja (purposive) dengan mempertimbangkan hal-hal berikut

1. Berdasarkan hasil studi penjajakan pada bulan September 2017 diketahui bahwa Manajer Rumah Kopi dan Galeri Seni Kopiganes telah menjabat lebih dari dua tahun sehingga diharapkan kepemimpinan yang telah dilaksanakannya dapat diteliti secara lebih mendalam.

2. Rumah Kopi dan Galeri Seni Kopiganes dengan sistem pemasaran via media sosial yang baik di Surabaya .

Penelitian lapangan dilaksanakan pada bulan Oktober sampai dengan Desember 2017 


\section{Teknik Pemilihan Responden dan Informan}

Dalam penelitian ini, teknik yang digunakan dalam menetapkan responden karyawan Rumah Kopi dan Galeri Seni Kopiganes adalah total sampling, yaitu pengambilan sampel sebesar populasi yang ada. Hal ini mengacu pada pendapat (Surakhmad, Winarno, 1989) bahwa adakalanya masalah penarikan sampel ditiadakan sama sekali dengan memasukkan seluruh populasi sebagai sampel, yakni semua jumlah populasi itu diketahui terbatas. Berdasarkan hasil studi penjajakan diketahui bahwa populasi seluruh karyawan Rumah Kopi dan Galeri Seni berjumlah 10 orang. Informan dalam penelitian ini adalah seluruh karyawan Rumah Kopi dan Galeri Seni Kopiganes. Disamping itu, untuk mengetahui faktor yang mempengaruhi manajer Rumah Kopi dan Galeri Seni Kopiganes dalam mengambil keputusan, yang dijadikan informan adalah manajer dari Rumah Kopi dan Galeri Seni Kopiganes.

\section{Teknik Pengumpulan Data}

Data yang akan dikumpulkan terdiri dari data primer dan data sekunder meliputi data kuantitatif dan data kualitatif. Data primer dikumpulkan dari para responden dan informan. Data primer yang dikumpulkan terdiri dari:

1. Gambaran Budaya organisasi pada Rumah Kopi dan Galeri Seni Kopiganes yang digunakan pemimpin/manajer dalam pengambilan keputusan.

2. Faktor-faktor yang mempengaruhi manajer Rumah Kopi dan Galeri Seni Kopiganes dalam mengambil keputusan. 


\section{Teknik Pengolahan dan Analisis Data}

Data yang diperoleh dari kuesioner akan diolah secara kuantitatif. Data kuantitatif diolah dan disajikan dalam bentuk tabel frekuensi dan tabulasi silang. Tabulasi silang digunakan untuk mengetahui pengaruh gaya kepemimpinan terhadap kinerja karyawan. Pengolahan dan analisis data kualitatif dilakukan dengan mereduksi (meringkas) data dengan menggolongkan, mengarahkan, membuang yang tidak perlu dan mengorganisasikan data sedemikian rupa sehingga sesuai dengan keperluan untuk menjawab pertanyaan analisis di dalam penelitian. Data hasil wawancara yang relevan dengan fenomena yang dianalisis, disajikan dalam bentuk kutipan-kutipan. Analisis data kualitatif dipadukan dengan hasil interpretasi data kuantitatif. 


\section{HASIL DAN PEMBAHASAN}

\section{Keadaan Rumah Kopi dan Galeri Seni Kopiganes}

Rumah Kopi dan Galeri Seni Kopiganes memiliki budaya organisasi yang cukup bagus karna hampir sebagian standar operasional yang ada di kopiganes tidak berjalan baik pada beberapa karyawan kopiganes yang rata-rata mahasiswa, sehingga manajer mengalami kesulitan terhadap pengambilan keputusan. Di kopiganes sendiri mempunyai produk yang sangat digemari oleh konsumen yaitu kopi manual brew dengan jenis kopi nusantara terutama kopi toraja enrekang. Dengan responden laki-laki sebanyak 8 orang dan wanita 2 orang teknik pengolahan data tarbulasi silang hasil dari penelitian ini menunjukkan bahwa budaya organisasi mempunyai dampak yang signifikan terhadap pengambilan keputusan di Rumah Kopi dan Galeri Seni Kopiganes.Hal ini terlihat dari uji Anova nilai signifikansi $<0.05$.

Sehingga membangun budaya organisasi melalui kepemimpinan adalah cara yang paling tepat untuk melakukan hal-hal yang menyangkut operasional kopiganes secara sistematis, sehingga seorang pemimpin yang mampu membangun budaya organisasi akan mendapatkan dukungan dalam pengambilan keputusan di sektor operasional kopiganes yang berdampak pada kualitas kopiganes. Pemimpin yang dapat memberikan contoh dalam memberikan pelayanan yang baik kepada pelanggan akan dikuti oleh karyawannya yang memberikan pelayanan yang memusakan pelanggannya(Alimudin, A., \& Artaya, 2009). 


\section{PENUTUP}

\section{Kesimpulan}

Faktor yang mempengaruhi manajer Rumah Kopi dan Galeri Seni Kopiganes dalam mengambil keputusan menentukan budaya organisasi yang berkelanjutan sehingga seluruh sumber daya manusia yang ada di kopiganes bisa menjalankan operasional kopiganes secara sistematis. Hal ini menunjukkan bahwasanya budaya organisasi sangatlah penting terhadap pengambilan keputusan manajer Rumah Kopi dan Galeri Seni Kopiganes dalam mengambil keputusan. 


\section{DAFTAR PUSTAKA}

Alimudin, A., \& Artaya, I. P. (2009). Persepsi Nasabah Tentang Ketanggapan, Keramahan, Kehandalan, Komunikasi, Dan Mengerti Nasabah Terhadap Pelayanan Bagian Prioritas PT. Bank Central Asia SurabayaNo Title. Bisnis Dan Manajemen, 1(2).

Alimudin, A., \& Sasono, A. D. (2015). Peningkatan daya saing produk konveksi usaha kecil berbasis iptek di desa tri tunggal kecamatan babat lamongan. In Seminar Nasional Teknologi Terapan SV UGM.

Alimudin, A., \& Sukoco, A. (2017). The Leadership Style Model That Builds Work Behavior Through Organizational Culture. JURNAL LENTERA: Kajian Keagamaan, Keilmuan Dan Teknologi, 3(2), 362-375.

Alimudin, A. (2013). PENGARUH ORIENTASI WIRAUSAHA TERHADAP KEUNGGULAN BERSAING BERKELANJUTAN DAN KINERJA PEMASARAN USAHA KECIL SEKTOR PERDAGANGAN (CONSUMER GOODS) DI KOTA SURABAYA. Sustainable Competitive Advantage (SCA), $3(1)$.

Alimudin, A. (2015). Strategi pengembangan minat wirausaha melalui proses pembelajaran. E-Jurnal Manajemen Kinerja, 1(1).

Hamka. (2017). Budaya organisasi dan pengambilan keputusan.

Ida Ayu Brahmasari, \& Agus Suprayetno. (2008). Pengaruh Motivasi Kerja, Kepemimpinan dan Budaya Organisasi Terhadap Kepuasan Kerja Karyawan serta Dampaknya pada Kinerja Perusahaan (Studi kasus pada PT. Pei Hai International Wiratama Indonesia). Jurnal Manajemen Dan Kewirausahaan, 10(1996), pp.124135. https://doi.org/10.9744/jmk.10.2.pp. 124-135

Nurhidayati, R. (2015). Pengaruh Budaya Organisasi dan Konsep Diri Terhadap Pengambilan Keputusan Kepala Sekolah Dasar Negeri I di Kecamatan Jagakarsa, (1), 1169-1177.

Pradhanawati, A., N, H. S., \& Si, M. (2012). DISIPLIN KERJA PADA KARYAWAN HARIAN SKT MEGAWON II PT . DJARUM KUDUS Kepemimpinan Transformasional Terhadap Kinerja Karyawan Melalui Disiplin Kerja ( Studi Kasus Karyawan Harian Bagian Produksi Djarum Coklat Pada Pt . Djarum Unit Kerja Skt Megawon Ii, 1-8.

Surakhmad dan Winarno. (1989). Pengantar penelitian ilmiah : dasar, metode dan teknik. Ilmiah, 14. 
Tarbiyah, S. (2017). Shautut Tarbiyah, Ed. Ke-36 Th. XXII, Mei 2017, 1-18.

Vitell, S. J., Nwachukwu, S. L., \& Barnes, J. H. (1993). The Effects of Culture on Ethical Decision-Making : An Application of Hofstede $€^{\mathrm{TM}} \mathrm{s}$ Typology. Journal of Business Ethics, 12(1984), 753-760. https://doi.org/10.1007/BF00881307 